ISSN (Print) : :1412-7601

ISSN (Online) : 2654-8712

Volume 5, No.2 September 2019

http://www.ekonobis.unram.ac.id

EKONOBIS

\title{
Pemberdayaan Masyarakat Pesisir Dalam Rangka Pengembangan Pariwisata Melalui Pengelolaan Desa Wisata Pantai Gili Gede Sekotong Kabupaten Lombok Barat
}

\author{
Masrun, Akhmad Jupri, M.Firmansyah
}

Universitas Mataram

\section{ARTICLE INFO}

\section{Keywords :}

Coastal Community

Empowerment, Tourism,

Tourism Village

ABSTRACT : The purpose of this study is expected to compile a coastal community empowerment program in the context of developing tourism in the coastal tourism village by involving local communities. The study was conducted using a field survey method with Participatory Rural Apraisal (PRA) participants in Gili Gede Sekotong Village, West Lombok Regency. DWP and the opportunities and business feasibility of small entrepreneurs and the mental and entrepreneurial spirit of micro small entrepreneurs in the Gili Gede area. Then there will be training in order to increase knowledge and skills related to small business management. The results showed that 1). Based on the results of the FGD to solve problems as a community empowerment program carried out through: Managing natural resources, enhancing human resources through skills training and business management (entrepreneurship) through mentoring the entrepreneurial mental / soul motivation with the needs of Higher Education, Local Government), Stocholder, NGOs and Society, 2). Of the three business sectors that are developed economically and are also feasible / superior developed in the village of Gili Gede Sekotong namely shredded tuna, goat livestock and trading businesses.

Kata Kunci :

Pemberdayaan

Masyarakat Pesisir,

Pariwisata, Desa Wisata
ABSTRAK: Tujuan dari penelitian ini diharapkan tersusunnya program pemberdayaan masyarakat pesisir dalam rangka pengembangan pariwisata pada lokasi Desa Wisata Pantai dengan melibatkat masyarakat lokal. Penelitian dilakukan dengan metode survey lapangan dengan pendekatan Participatory Rural Apraisal (PRA) di Desa Gili Gede Sekotong Kabupaten Lombok Barat. Kegiatan ini untuk mengidentifikasi seluruh potensi pengembangan pesisir dan laut DWP dan peluang dan kelayakan usaha dari pengusaha kecil mikro serta mengidentifikasi mental dan jiwa wirausaha dari pengusaha kecil mikro di kawasan Gili Gede. Selanjutnya dilakukan pelatihan dalam rangka untuk meningkatkan pengetahuan dan ketrampilan yang terkait dengan pengelolaan usaha kecil. Hasil penelitian menunjukkan bahwa 1). Berdasarkan hasil FGD untuk memecahkan permasalahan sebagai program pemberdayaan masyarakat dalam pengembangan pariwisata dilakukan melalui : pengolahan sumberdaya alam secara proporsional, peningkatan sumberdaya manusia melalui pelatihan ketrampilan dan pengelolaan usaha (kewirausahaan) melalui pembinaan sikap mental/jiwa wirausaha dengan melibatkan Perguruan Tinggi, Pemda (instansi terkait), Stocholder, LSM dan Masyarakat, 2). Dari tiga bidang usaha yang dianalisis secara ekonomi menguntungkan dan juga layak/unggul dikembangkan untuk sementara di Desa Gili Gede Sekotong yaitu usaha abon ikan tongkol, ternak kambing dan usaha dagang.

Corresponding Author :

Alamat : Program Studi Ekonomi Pembangunan, Fakultas Ekonomi dan Bisnis, Universitas Mataram, Jln. Majapahit No. 62 Mataram.

e-mail: masrun@unram.ac.id 


\section{PENDAHULUAN}

\section{Latar Belakang}

Pariwisata Indonesia sekarang ini semakin meningkat dengan banyaknya destinasi pariwisata yang tersebar diseluruh pelosok tanah air. Salah satu penjabaran dan sasaran pembangunan Nasional adalah pembangunan sektor pariwisata. Berbagai dasar pemikiran telah dirumuskan sebagaia pedoman dalam pembangunan kepariwisataan pada masa mendatang yang penuh dengan harapan dan tantangan. Konsep pembangunan kepariwisataan berbasis masyarakat menetapkan masyarakaat sebagai bagian yang terpisahkan dari produk wisata. Produk pariwisata merupakan proses rekayasa sosial (social engenering) masyarakat dan esensi pembangunan pada komunitas atau masyarakat (communiti based development). Konsep pembangunan tersebut merupakan salah satu pendekatan yang memiliki nilai strategis. Di satu pihak, pendekatan ini diyakini mampu menciptakan produk wisata yang bercirikan lokal sebagian modal dasar perencanaan dan pemasaran produk, dilain pihak, akan dapat menciptakan ketahanan dan kesetabilan sosial ekonomi masyarakat. Dengan demikian pembangunan pariwisata yang bertumpu pada kekuatan masyarakat dapat berfungsi sebagai aset dan kekuatan dasar kepariwisataan nasional dan daerah

Desa Wisata Pantai (DWP) pada hakekatnya adalah mengembangkan dan memanfaatkan obyek serta daya tarik wisata bahari di kawasan pesisir dan laut, berupa kekayaan laut yang indah, keragaman flora dan fauna. Dengan potensi yang demikian besar, dapat memberikan manfaat bagi pembangunan umumnya dan peningkatan pendapatan masyarakat khususnya, maka dalam pelaksanaannya dibutuhkan strategi yang terencana, sistematis dan terintegrasi dengan pengembangan masyarakat nelayan yang aktivitas umumnya tidak lepas dari laut dan pantai. Artinya, pengembangan wisata tidak bisa pada kepentingan pemilik modal saja. Keterlibatan atau partisipasi masyarakat lokal menjadi penting, termaksud dalam kaitannya dengan upaya berkelanjutan Desa Wisata Pantai itu sendiri dalam hal perlindungan terhadap lingkungan maupun peningkatan bagi kesajahteraan masyarakat (Kay R \& Alder, 1999).

Wisata bahari banyak ditonjolkan oleh pemerintah kabupaten/kota di Indonesia saat ini. Hal ini dapat dimengerti karena memang banyak wilayah Daerah Tingkat II 
yang memiliki pesisir dengan penduduknya rata-rata miskin. Demikian pula pemerintahan daerah Lombok Barat yang memiliki sejumlah kawasan wisata potensial yang belum berkembang mulai dari Lombok Barat bagian utara hingga Lombok Barat bagian selatan. Salah satunya adalah kawasan Gili Gede yang berada di kampung atau desa nelayan. Bentuk perhatian pemerintah daerah pada kawasan ini adalah menjadikan Gili Gede sebagai salah satu kawasan pengembangan wilayah pesisir dan laut. Gili Gede berjarak sekitar 40 kilometer dari mataram ibukota provinsi Nusa Tenggara Barat, di teluk ini terdapat pantai pesisir putih dimana para nelayan dapat mendaratkan dan memarkir perahunya. Selain panoramanya indah dengan adat istiadat yang khas, juga terdapat satu bungalow milik warga negara asing.

Rencana Pengembangan Desa Wisata Pantai (DWP) dikawasan Gili Gede Lombok Barat adalah salah satu bentuk alternatif modal pembangunan ekonomi daerah yang diharapkan mampu membuka dan mendorong peluang kreativitas lokal. Kenyataan selama ini terjadi, pertumbuhan pariwisata khususnya di Pulau Lombok terjadi kepincangan, dimana sebagian besar kunjungan wisatawan masih terkonsetrasi pada daerah tertentu. Kepincangan kunjungan wisata tersebut, merupakan tantangan tersendirinya bagi daerah, oleh karena itu untuk mencapai pertumbuhan yang memadai perlu dipacu pertumbuhannya. Pengembangan perencanaan yang jelas dan prosesnya melibatkan masyarakat lokal, baik dari sisi peran maupun dari sisi penerima dampak dan manfaat dari wisata tersebut. Kelengkapan berbagai sarana pendukung bagi suatu kawasan yang hendak di kembangkan merupakan syarat bagi kawasan wisata yang berciri aktivitas nelayan.

Hasil pengabdian pada masyarakat tahun 2006 yang telah dilakukan oleh Konsorsium Program Mitra Bahari Ragional Center NTB pada kawasan Gili Gede ditemukan beberapa keunggulan antara lain : panorama yang cukup indah dan merupakan pulau kecil yang jaraknya tidak bergitu jauh dari pantai yang jaraknya kurang lebih 1 mil, kepemilikan lahan adalah milik masyarakat (bukan investor), kondisi sosial masyarakat cukup mendukung, dukungan pemerintah daerah cukup besar, sarana jalanan cukup baik dan transportasi cukup lancar. Namun terdapat beberapa kelemahan yang ditemukan antara lain : infra struktur 
pengunjung seperti telepon belum ada, sumber daya manusia khususnya yang terkait dengan keterampilan pariwisata dan kekuatan masih rendah.

Dengan demikian perlu adanya penelitian tentang model pemberdayaan masyarakat pesisir dalam rangka pengembangan pariwisata melalui pengelolaan Desa Wisata Pantai Gili Gede Sekotong Kabupaten Lombok Barat. Pengembangan perencanaan yang jelas dan prosesnya melibatkan masyarakat lokal, baik dari sisi peran maupun dari sisi penerima dampak dan manfaat dari wisata tersebut. Kelengkapan berbagai sarana pendukung bagi suatu kawasan yang hendak di kembangkan merupakan syarat bagi kawasan wisata yang berciri aktivitas nelayan.Beranjak dari kondisi demikian, perencanaan dan pengembangan desa wisata pantai merupakan bentuk perencanaan yang strategis yang dapat diharpkan mendorong percepatan perkembangan wilayah. Proses perencanaan pengembangan desa wisata pantai merupakan suatu proses dalam upaya mengidentifikasi potensi, peluang dan kendala beserta aktivitas sosial ekonomi didalamnya, memenuhi kebutuhan dan aspirasi stakehholder tentang arah dan bentuk pengembangan kedepan, merumuskan alternatif pengembangan desa wisata panatai secara optimal dengan memperhatikan aspek-aspek biofisik wilayah, sosial budaya dan sosial ekonomi wilayah.

Diharapkan dalam pengembangan Desa Wisata Pantai (DWP) :

1. Bedasarkan kearifan lokal mendorong meningkatnya pendapatan masyarakat sekitar kawasan.

2. Tersusunnya program pengembangan kawasan pesisir DWP dengan melibatkan masyarakat lokal.

Esensi desa wisata adalah pengembangan suatu wilayah (desa) dengan memanfaatkan kemampuan unsur-unsur yang ada dalam masyarakat dan desa yang berfungsi sebagai atribut produk wisata, menjadi suatu aktivitas pariwisata yang terpadu. Pengertian terpadu adalah desa sebagai produk wisata mampu menyediakan dan memenuhi serangkaian kebutuhan dan perjalanan wisata, baik aspek daya tarik maupun berbagai fasilitas pendukungnya. Berangkat dari esensi tersebut, maka desa wisata merupakan suatu wilayah pedesaan yang menawarkan keseluruhan suasana yang mencermikan keaslian pedesaan, baik dari segi lingkungan alam (pantai pesisir 
dengan panoramanya, pulau-pulau kecil dan biota lautnya), kehidupan sosial ekonomi, sosial budaya, adat istiadat keseharian, memiliki arsiterktur bangunan, dan struktur tata ruang desa yang khas maupun aspek historinya, serta mempunyai potensi untuk dikembangkannya berbagai komponen kepariwisataannya.

Bedasarkan arah kebijakan pengelolaan pesisir dan pantai di Propinsi Nusa Tenggara Barat, maka sejak tahun 1997 pemerintahan daerah telah mengembangkan konsep pengembangan desa yang dikenal dengan nama Gerbang Masa Depan (Gerakan Pembangunan Masyarakat Desa Pantai). Gerakan pembangunan masyarakat desa pantai dilatar belakangi oleh keinginan untuk mamacu perkembangan kawasan yang cukup besar, sekaligus untuk mengurangi disparitas antara kawasan pantai dengan kawasan non-pantai yang relatif lebih maju. Namun hasil kesimpulan Work Shop Singapura Airlines yang diselenggarakan di Singapura pada tahun 2000, diungkapkan bahwa Pulau Lombok perlu diperbanyak "Desa Wisata". Munculnya kesimpulan diatas, karena didasarkan atas perkiraan ke depan, bahwa kunjungan dari Pulau Dewata (Bali) akan meningkat secara drastis, oleh karena itu pulau Lombok sebagai alternatif pelimpahannya, disamping itu jumlah desa wisata sebagai obyek kunjungan wisata yang ada, masih relatif sedikit.

\section{TINJAUAN PUSTAKA}

Pengembangan desa wisata harus dilaksanakan secara sehari-hari agar dampak yang timbul dapat dikontrol.Berdasarkan dari penelitian dan studi-studi dari UNDR/WTO dan beberapa konsultan indonesia, dicapai dua pendekatan dalam menyusun rangka kerja/konsep kerja dari pengembangan sebuah Desa menjadi desa wisata. Pendekatan pasar untuk pengembangan Desa Wisata terdiri dari :

1. Interaksi tidak langgsung, suatu mode pengembangan didekati dengan cara bahwa desa dapat manfaat tanpak interaksi lansung dengan wisatawan. Bentuk kegiatan yang terjadi seperti:penulisan buku-buku tentang desa yang berkembang, kehidupan desa,arsitektur internasional, latar belakang sejarah, pembuatan kartu pos dan sebagainya.

2. Interaksi setengah langsung, suatu bentuk one day trip yang dilakukan oleh wisatawan, kegiatan-kegiatan 
meliputi makan dan kegiatan bersama penduduk dan kemudian wisatawan dapat kembali ke tempat akomodasinya. Prinsip model tipe ini adalah bahwa wisatawan hanya singgah dan tidak tinggal bersama penduduk.

3. Interaksi langsung, suatu wisatawan di mungkinkan untuk tinggal atau bermalaman dalam akomodasi yang dimiliki oleh desa tersebut. Dampak yang terjadi dapat dikontrol dengan berbagai pertimbangan yaitu daya dukung dan potensi masyarakat setempat. Alternatif lain dari model ini adalah penggambungan dari model pertama dan kedua.(Anonimaus,1981).

Syah (2003) mengemukakan bahwa pendekatan fisik pengembangan desa wisata.merupakan solusi yang umum dalam mengembangkan sebuah desa melalui sektor pariwisata dengan mengunakan standar-standar khusus dalam mengontrol perkembangan dan menerapkan aktivitas konservasi.

Mengkorserpasi sejumlah rumah yang memiliki nilai budaya dan arsitektur yang tinggi dan menggubah fungsi rumah tinggal menjadi sebuah museum dan untuk menghasilkan biaya untuk pariwisata dari rumah tersebut. Contoh pendekatan dari tipe pengembangan model ini adalah Desa Wisatawan di Koanara, Flores. Desa wisata yang terletak di daerah wisata Gunung Kelimutu ini mempunyai aset wisata budaya berupa rumah-rumah tinggal yang memiliki arsitektur yang khas.dalam mengkonserpasi dan mempertahankan rumah-rumah tersebut,penduduk desa menempuh cara memusiumkan rumah tinggal penduduk yang masih ditinggali.untuk mewadahi yang akan mendaki Gunung Kelimutu dengan fasilitas berstandar resor minimum dan kegiatan budaya lain.

Mengkonservasi keseluruhan desa dan menyediakan lahan baru untuk menampung perkembangan penduduk desa tersebut sekaligus mengembangkan lahan tersebut sebagai area pariwisata dengan fasilitas-fasilitas wisata. Contoh pendekatan pengembangan desa wisata jenis ini adalah Desa Wisata Sade, di Lombok

Mengembangkan bentuk-bentuk akomodasi di dalam wisata desa tersebut yang dioperasikan oleh penduduk desa tersebut sebagai industri skala kecil. Contoh dari bentuk pengembangan ini adalah desa wisata Wolotopo di Flores. Aset wisata di daerah ini sangat beragam 
antara lain : kerajinan tenun ikat, tarian adat, rumah-rumah tradisional dan pemendangan ke laut. Wisata di daerah ini dikembangkan dengan membangun perkampungan berskala kecil di dalam lingkungan Desa Wolotopo yang menghadap ke laut dengan atraksi-atraksi budaya yang unik. Fasilitas-fasilitas wisata ini di kelola sendiri oleh penduduk desa setempa. Fasilitas wisata berupa akomodasi bagi wisatawan, restauran, kolam renang, peragaan tenun ikat, plaza,kebun dan dermaga perahu boat.

Pengembangan kawasan Desa Wisata Pantai (DWP) dapat diharapkan memenuhi prinsip-prinsip (Eddy Ahmad, dkk, 2009) sebagai berikut :

Tidak bertentangan dengan adat atau budaya masyarakat desa setempat.

Pengembangan suatu desa wisata harus memperlihatkan beberapa aspek yang berkaitan dengan kehidupan sosialbudaya, adat istiadatnya dan mata pencarian desa tersebut. Suatu desa yang tata cara dan adat istiadatnya masih mendominasi pola kehidupan masyarakatnya, dalam pembangunan sebagai atraksi wisata harus disesuaikan dengan situasi ataupun tata cara yang berlaku didesa tersebut.

Pengembangan fisik yang dilakukan ditunjukan untuk meningkatkan kualitas lingkungan desa. Pengembangan pariwisata disuatu desa pada hakekatnya tidak merubah apa yang sudah ada di desa tersebut, tetapi lebih kepada upaya menggali potensi yang ada dan mengemasnya sedemikian rupa sehingga menarik untuk dijadikan atraksi wisata.

Memperhatikan unsur kelokalan dan keaslian. Arsitektur bangunan, serta material yang digunakan dalam pembanguan haruslah menonjolkan ciri khas keaslian wilayah setempat. Bahabahan/material yang digunakan untuk bangunan rumah, interior, peralatan makan/minum, dan fasilitas lainnya hendaknya memberikan nuansa yang alami dan menggambarkann unsur kelokalan dan keaslian.

Memberdayakan masyarakan masyarakat desa. Masyarakat terlibat langsung dalam kegiatan pariwisata dalam bentuk pemberian jasa dan pelayanan yang hasilnya dapat meningkatkan pendapatan masyarakat. Beberapa bentuk keterlibatan masyarakat tersebut adalah penyediaan fasilitas akomondasi, penyediaan kebutuhan konsumsi wisatawan, pemandu wisata, transportasi lokal pertunjukan kesenian, dan lain-lain. Memperhatikan daya dukung dan daya tampung serta berwawasan lingkungan. Pengembangan suatu desa wisata harus 
memperhatikan kapasitas desa tersebut, baik kapasitas fisik maupun kesiapan masyarakat. Prinsip- perinsip pariwisata yang berkelanjutan (sustainable tourism) harus mendasari pengembangan desa wisata pantai.

Memperhatikan daya dukung dan daya tampung serta berwawasan lingkungan. Pengembangan suatu desa wisata harus memperhatikan kapasitas desa tersebut, baik kapasitas fisik maupun kesiapan masyarakat. Prinsip- perinsip pariwisata yang berkelanjutan (sustainable tourism) harus mendasari pengembangan desa wisata pantai.

Pada prinsipnya terdapat 3 (tiga) tujuan yang hendak dicapai dari arah kebijakan mengelola pesisir dan laut di Propinsi NusaTengara Barat, yaitu:

1. Membentuk basis data, kelembagaan, dan peningkatan ketrampilan dalam pemanfatan sumberdaya pesisir dan laut yang saling mendukung dengan basis data yang di siapkan Land Resauces Evaluation and Planning (LREP);

2. Peningkatan kemampuan perencanaan dan pengelolaan pesisir dan laut Propinsi NTB melalui penyusunan rencana stategi (Renstra) dan
3. Pengembangan dan peningkatan sistem informasi pesisir dan kelautan yang sudah ada dalam memaksimalkan manfaat yang dapat diperoleh melalui optimalisasi pemanfaatan dan pengelolaan sumber daya pesisir dan laut.

4. Konsep pokok pengembangan masyarakat desa pantai adalah pembangunan terpadu atas aspekaspek sosial dan ekonomi masyarakat yang bertempat tinggal diwilaya pantai. Pengertian terpadu adalah dengan melibatkan semua unsur pemerintah dan masyarakat dalam proses pembangunan. Dengan demikian semua pihak akan merasa dilibatkan,dan merasa bertanggung jawab atas keberhasilan program tersebut. Oleh karena itu, perlu disusun metode pembangunan yang tepat, dengan sasaran akhir peningkatan kehidupan sosial dan ekonomi masyarakat desa pantai.melalui pemanfaatan segenap potensi yang ada dan di dukung dengan sarana dan prasarana yang sudah ada, selain dengan membangun sarana dan prasarana baru yang 
perlu yang benar-benar diperlukan. Adapun tujuan spesifik yang hendak dicapai dari pembangunan masyarakat dan pantai tersebut adalah :

Meningkatkan pertumbuhan, pemerataan serta keterkaitan antar desa-desa antar kota dengan desa

Meningkatkan keterpaduan perencanaan dan sinkronisasi pembangunan oleh istansi sektoral, daerah, swasta serta masyarakat

Meningkatkan pembangunan partisifati masyarakat desa pantai, serta mengengembangkan sektor-sektor kunci maupun sektor unggulan sebagai motor pengerak pembangunan desa pantai

Meningkatkan efesiensi dan efektivitas investasi pemerintah, swasta serta masyarakat dalam pengembangan kawasan pantai

Mendorong terwujudnya pembangunan yang berkelanjutan serta berwawasan lingkungan umumnya dan desa pantai pada kususnya.

Tujuan dari pembangunan masyarakat desa pantai tersebut diplementasikan dengan menerapkan beberapa strategi sebagai berikut:

1. Berpangkal tolak dari pemberdayaan masyarakat
2. Sejalan dengan pembangunan sektoral;

3. Pengembangan sarana fisik,dan kelembagaan;

4. Pengembangan sumberdaya masyarakat

5. Mendorong investasi swasta dan masyarakat;

6. Penjabaran terhadap program pembangunan masyarakat desadesa pantai.

\section{METODE PENELITIAN}

Penelitian dilakukan dengan metode survey lapangan di Gili Gede Desa Wisata Pantai Sekotong. Perencanaan dan pengembabangan desa wisata pantai bentuk pelaksanaan strategis yang dapat mendorong percepatan perkembangan wilayah. Proses perencanaan pengembangan desa wisata pantai melalui upaya mengidentifikasi potensi, peluang dan kendala serta aktivitas sosial eknomi dialaminya, memahami kebutuhan dan aspirasi stakeholder tentang arah dan bentuk pengembangan ke depan, merumuskan alternative pengembangan secara optimal dengan mengkaji aspek-aspek lingkungan alam, sosial budaya dan sosial ekonomi setempat. Selanjutnya dilakukan pelatihan dalam rangka untuk meningkatkan 
pengetahuan dan ketrampilan yang terkait dengan pengelolaan desa wisata pantai. Kegiatan ini, diharapkan para masyarakat/pengelola dapat meningkatkan kualitas dan kuantitas hasil usahanya sehingga akan mendorong peningkatan

pendapatan/penghasilannya.

Luaran penelitian ini, untuk menghasilkan Model/Program Pemberdayaan Masyarakat Di Kawasan Pesisir Desa Wisata Pantai Di Gili Gede Sekotong Kabupaten Lombok Barat. Selanjutnya hasil penelitian ini akan dipublikasikan pada Jurnal Ilmiah Fakultas Ekonomi dan Bisnis Universitas Mataram.

Lokasi penelitian adalah kawasan pesisir Desa Wisata Pantai Gili Gede Sekotong Kabupaten Lombok Barat. Daerah ini terdapat potensi lokal yang belum optimal dikelola oleh masyarakat dan kondisi ekonominya tergolong miskin serta tidak memiliki kemampuan pengelolaan dalam pengembangan pariwisata.

Metode pengumpulan data melalui survey lapangan dengan pendekatan Participatory Rual Apraisal (PRA), dimana dilibatkan masyarakan terhadap perencanaan, pelaksanaan, monitoring maupun sampai evaluasi. Pendekatan PRA menjamin rasa memiliki dari masyarakat terhadap program, sehingga aspek berkelanjutan program akan sangat terjamin. Kemudian analisis data yang digunakan dalam penelitian ini dengan berpedoman pada analisis Deskriptif dan AHP untuk mengetahui produk prioritas (potensi lokal), sedangkan Biaya dan Pendapatan untuk mengetahui peluang dan kelayakan usaha.

\section{HASIL DAN PEMBAHASAN}

\section{Kondisi umum Desa Gili Gede}

Kawasan perairan Gili Gede memiliki pantai berpasir dengan topografi landai dan perairannya yang jernih serta mudah diakses, dan terdapat sumberdaya alam yang relative besar khususnya pesisir dan laut, tapi karena belun dikelola/diperdayakan secara optimal. Dampak kondisi tersebut, saat ini obyek wisata belum banyak dikunjungi oleh wisatawan lokal maupun mancanegara. Sehingga tingkat kesejahteraan masyarakat juga akan mempengaruhinya, padahal Desa Gili Gede secara ekonomi dan sosial dapat mempercepat pertumbuhan ekonomi karena memiliki nilai strategi dan keunggulan pada sumberdaya alam.

Mangrove (hutan bakau) merupakan sumberdaya alam yang mempunyai manfaat serbaneka (multiple uses) dengan pengaruh yang sangat luas 
ditinjau dari aspek sosial ekonomi dan aspek ekologi. Besarnya peranan hutan mangrove dipandang dari segi ekologi bagi kehidupan dapat diketahui dari banyaknya jenis binatang dan tumbuhan termasuk manusia yang hidupnya tergantung pada hutan mangrove. Masyarakat di kawasan Gili Gede pada umumnya sangat memahami arti dan fungsi hutan mangrove bagi kehidupan mereka, namun seringkali karena alasan ekonomi (kebutuhan keluarga dalam rumah tangga), masyarakat cenderung mengabaikan fungsi hutan mangrove untuk mendapatkan keuntungan ekonomi dalam waktu cepat. Masyarakat melakukan penebangan pohon mangrove karena berbagai peruntukan seperti membuka lahan tambak, pemukinan serta kayu mangrove dengan berbagai kepentingan untuk kayu bakar.

Penanggulangan terhadap kondisi tersebut, program yang dilakukan melalui pendekatan secara kelembagaan baik formal maupun informal untuk merubah sikap mental dan perilaku masyarakat. Pemecahan terhadap persoalan ini memang tidak mudah mengingat disisi lain kenaikan BBM yang semakin meningkat merupakan salah satu ancaman bagi pengrusakan habitat mangrove kedepan, karena sebagian besar masyarakat di sekitar kawasan Desa Gili Gede dalam kondisi ekonomi yang lemah. Oleh karena itu perlu segera diantisipasi melalui mata pencaharian alternative. Melalui pola ini diharapkan masyarakat akan mendapatkan manfaat ekonomi dan pada saat yang bersamaan upaya peningkatan pengetahuan dan kesadaran masyarakat dapat terwujud, sehingga dapat mengurangi tekanan terhadap sumberdaya mangrove dan pada gilirannya berpengaruh pada aspek kelestarian mangrove bisa terjaga.

Sumberdaya alam lain yang memiliki daya tarik tersendiri dan potensial adalah pada kawasan Gili Gede adalah terumbu karang. Dibeberapa tempat terdapat gugusan terumbu karang yang potensial untuk dipertahankan sebagai habitat ikan dan sebagai lokasi obyek wisata bahari. Kondisi terumbu karang di sekitar kawasan Gili Gede sebagian relatif masih baik dan sebagian lagi telah mengalami kerusakan yang cukup serius akibat penangkapan ikan dengan menggunakan bom. Oleh karena bagi lokasi dengan terumbu karang yang masih baik itu harus dipertahankan, sedangkan bagi lokasi yang telah mengalami kerusakan harus dilakukan rehabilitasi dan tranplantasi. Nelayan di kawasan Desa Gili Gede sebagian besar/hampir seluruhnya 
merupakan nelayan kecil/miskin. Keberadaan nelayan tersebut cukup memprihatinkan yang ditandai dengan kondisi social ekonomi yang tergolong miskin. Salah satu penyebabnya adalah sebagian masyarakat nelayan memiliki sarana penangkapan yang kurang memadai. Umumnya sarana penangkapan yang dimiliki masih berupa alat tangkap tradisional, sehingga nelayan masih memiliki keterbatasan dalam memperoleh hasil tangkapan. Kecilnya pendapatan yang diterima nelayan karena rendahnya kepemilikan modal dan kapasitas alat tangkap yang dimiliki, sehingga aktivitas penangkapan hanya di wilayah tertentu dan jenis ikan yang tidak bernilai ekonomis tinggi. Fenomena ini terjadi karena selama ini belum pernah mendapat bantuan sarana penangkapan modern dari pemerintah, sedangkan untuk membeli sarana penangkapan yang modern masyarakat nelayan tidak memiliki modal yang cukup.

Tingkat pendidikan di kawasan Desa Gili Gede Sekotong tergolong rendah. Ini sebagai gambaran dengan masih banyaknya jumlah penduduk yang berpendidikan Sekolah Dasar dan tidak/belum Tamat Sekolah Dasar. Berdasarkan Profil Desa, bahwa penduduk yang tidak pernah $43,34 \%$, dan penduduk berpendidikan Sekolah Dasar (SD) yakni 30.64\%. Untuk penduduk yang memiliki pendidikan Sekolah Menengah Pertama (SLTA) dan Sekolah Menengah Atas (SLTA) masing-masing $12,01 \%$ dan $7,48 \%$, sedangkan PAUD/TK 4,44\%. Selanjutnya penduduk yang tingkat pendidikan yang paling tinggi tergolong sangat sedikit hanya $2,09 \%$.

Tingkat kesehatan di kawasan Desa Gili Gede masih tergolong rendah, tetapi sekarang sudah ada kemajuan bila dibandingkan dengan waktu-waktu yang lalu. Tingkat derajat kesehatan merupakan salah satu indikator tingkat kesejahteraan masyarakat. Antara kesehatan dengan kesejahteraa memiliki korelasi, semakin tinggi tingkat kesejahteraan masyarakat semakin tinggi derajat kesehatannya. Masyarakat kebutuhan primernya telah terpenuhi, termasuk aspek kesehatan berarti bisa dikatakan sejahtera. Kesehatan di kawasan Gili Gede Sekotong diarahkan agar pelayanan kesehatan meningkat lebih luas, lebih merata dan lebih terjangkau sehingga dapat menghasilkan derajat kesehatan masyarakat yang lebih tinggi, pada akhirnya setiap orang bisa hidup lebih produktif secara sosial maupun secara ekonomis. 
Dari sisi aspek sosial kependudukan dan tenaga kerja di kawasan Desa Gili Gede masih menampakkan kondisi yang kurang menguntungkan baik dari aspek kuantitas maupun kualitas. Sementara dari kondisi sosial kependudukan dan tenaga kerja di Desa Sekotong Tengah, Kabupaten Lombok Barat bila dicermati melalui beberapa indikator seperti kelompok umur penduduk, angka ketergantungan, tingkat pendidikan, angkatan kerja, pekerjaan utama dan tingkat pendidikan penduduk umur kerja masih memerlukan langkah-langkah operasional untuk dapat menggerakkan potensi penduduk secara optimal.

Masyarakat sebagai responden yang mendapat binaan dalam sasaran pelatihan dan pendampingan pada penelitian dengan karekteristik :

\section{Usia Pengusaha}

Umur/usia pengusaha binaan di lokasi penelitian bervariasi dengan kisaran umur antara 22 - 57 tahun. Dalam hubungannya dengan produktivitas, sebagian besar responden pengusaha binaan tergolong umur produktif.

2. Tingkat Pendidikan

Cerminan tingkat penguasaan seseorang terhadap suatu pengetahuan yang aplikasinya terlihat sebagai sikap wirausahanya adalah tingkat pendidikan. Selain itu, tingkat pendidikan juga memiliki peranan yang sangat besar dalam proses penerapan teknologi dan inovasi baru. Umumnya tingkat pendidikan pengusaha binaan yang dominan adalah tingkat Sekolah Menengah Pertama (SMP) sekitar 50 persen, sedangkan tingkat pendidikan Sekolah Dasar (SD) sebanyak 35 persen dan Sekolah Menengah Atas (SMA) kurang lebih 15 persen.

\section{Bidang Usaha}

Setelah diinventarisir bidang usaha yang digeluti oleh masyarakat binaan, sebagian besar adalah usaha abon ikan tongkol, kemudian disusul ternak kambing dan usaha dagang.

4. Modal Usaha

Modal usaha yang digunakan pengusaha mengandalkan modal sendiri karena sebagian besar yang digunakan dalam pengelolaan usaha, sedangkan modal pinjaman hanya sebagian kecil saja. Bagaimanapun modal usaha ini sangat dibutuhkan didalam pengembangan usahanya, oleh karena itu perlu dicarikan solusi untuk mendapatkannya, misalnya bantuan kredit lunak, dana bergulir dan lain sejenisnya.

5. Hasil Penjualan dan Keuntungan/Laba Usaha 
Rata-rata per bulan hasil penjualan dari pengusaha binaan bervariasi yaitu berkisar antara Rp 2.000.000,- sampai Rp 8.000.000,- . Sedangkan secara rata-rata per bulan hasil penjualan dari 20 pengusaha binaan adalah sebesar $\mathrm{Rp}$ 3.295.000,-. $\quad$ Selanjutnya untuk mengetahui tingkat keuntungan, ternyata rata-rata per bulan juga bervariasi dengan kisaran antara Rp 750.000,- sampai Rp 5.250.000,-. Sedangkan secara keseluruhan rata-rata per bulan per pengusaha kurang lebih sebesar $\mathrm{Rp}$ 2.280.000,-

\section{Peluang dan Kelayakan Usaha di}

\section{Kawasan Gili Gede Sekotong.}

Ketiga usaha di atas yang memungkinkan untuk dikembangkan di kawasan pesisir Desa Gili Gede Sekotong dengan berdasarkan hasil observasi lapang dan kajian komprehensif terhadap aspek fisik-biologis, dan kesesuaian sumberdaya alam dan lingkungan, aspek ekonomi, serta aspek sosial dan aspek kelembagaan. Dalam analisis peluang dan kelayakan usaha ini, dilakukan dengan kajian disajikan hasil analisis biaya dan pendapatan usaha abon ikan tongkol, usaha dagang dan usaha beternak kambing yang dilakukan secara tradisional.

1.Usaha Abon Ikan Tongkol
Hasil tangkapan ikan tongkol di kawasan Desa Gili Gede Sekotong tergolong tinggi, hanya masalahnya dari produk (ikan) tangkapan tersebut pemanfaatan yang masih terbatas. Tidak diolah agar memiliki nilai tambah, namun hanya dikonsumsi segar langsung, diasinkan dan diasap atau dipindang. Padahal dengan sentuhan teknologi pasca panen yang sederhana, hasil tangkapan ikan tongkol tersebut dapat diolah menjadi produk abon ikan tongkol yang memberikan nilai tambah pada produk tersebut yang pada gilirannya dapat meningkatkan pendapatan dan kesejahteraan nelayan maupun masyarakat di kawasan Desa Gili Gede Sekotong. Kajian analisis dari segi biaya dan pendapatan usaha abon ikan tongkol sama dengan yang lain diusahakan secara tradisional, menunjukkan bahwa biaya yang dikeluarkan pengusaha abon ikan tongkol dalam operasional satu bulan Rp 250.000 dengan pendapatan bersihnya $\mathrm{Rp}$ 2.250.000.

Pendapatan bersih atau Gross Margin sebesar tersebut termasuk menguntungkan secara ekonomi,--. tetapi kalau dilihat sisi penggunaan biaya operasional usahanya tidak efisien karena nilai Gross Ratio sebesar 10\% (kurang dari $20 \%$ sebagai indikator). Sementara pada 
tingkat profitabilitas juga menguntungkan ini dikarenakan nilai Contribution Margin (CM) mampu memberikan 90\% (indicator diatas 60\%), artinya pengelolaan biaya tetap dalam proses produksinya tergolong efisien. Usaha abon ikan tongkol layak dikembangkan di Desa Gili Gede Sekotong, dapat dibuktikan dari nilai Gross B/C Ratio (GR) sebesar 10\% (indikator diatas 20\%).

\section{Usaha Ternak Kambing}

Desa Gili Gede Sekotong merupakan wilayah yang cukup potensial bagi pengembangan peternakan, salah satunya adalah kambing dan unggas. Usaha peternakan merupakan industri pangan yang terbukti mampu menghasilkan nilai ekonomi yang tinggi dan dukungan pangsa pasar yang luas, ketersediaan lahan yang potensial dan dukungan kebijakan pemerintah. Beberapa tahun terakhir ini, usaha ternak kambing merupakan salah satu kegiatan masyarakat di kawasan Desa Gili Gede Sekotong yang memberikan sumbangsih terhadap pendapatannya selain usaha lain.

Hasil analisis biaya dan pendapatan usaha beternak kambing menunjukkan bahwa biaya yang dikeluarkan dalam satu siklus produksi sebesar $\mathrm{Rp} 450.000$ yang berlangsung selama enam bulan. Usaha ternak kambing dapat dikatakan menguntungkan secara ekonomi, dilihat dari nilai Gross Margin (GM) atau pendapatan bersih sebesar $\mathrm{Rp}$ 3.150.000,-. Pada tingkat profitabilitasnya, usaha ini juga menguntungkan dengan nilai Contribution Margin (CM) diatas $60 \%$ artinya pengelolaan biaya keseluruhan dalam proses produksinya tergolong efisien. Dari sisi kelayakan dengan nilai Gross B/C Ratio diatas 1,0 maka usaha ini layak dikembangkan, namun disisi penggunaan biaya operasionalnya tidak efisien dikarenakan nilai Gross Ratio kurang dari indikator $20 \%$ artinya biaya operasional yang dikeluarkan pengusaha ternak kambing satu siklus proses produksi (6 bulan) kurang $20 \%$ dari nilai produksi yang diperoleh.

\section{Usaha Dagang}

Setiap pedagang mempunyai tujuan yang ingin dicapai yaitu untuk mendapatkan laba/keuntungan, disamping tujuan lain seperti kelangsungan kontinuitas usaha dagang itu sendiri. Terakhir yang dianalisis biaya dan pendapatan dalam penelitian ini adalah usaha dagang. Kajian atau analisis pada usaha dagang sama dengan usaha lain dilakukan dengan manajemen sederhana. Kajian hasil analisis biaya dan pendapatan usaha 
dagang berdasarkan pada table 6 di atas, menunjukkan bahwa biaya operasional yang dikeluarkan dalam satu bulan usaha sebesar Rp 3.655.000 dengan keuntungan Rp 1.815.000.

Dari sisi ekonomi usaha dagang sama kondisinya dengan usaha lain dapat dikatakan menguntungkan, karena mampu memberikan nilai Gross Margin (GM) atau pendapatan bersih yang disebutkan diatas. Namun demikian pada sisi tingkat profitabilitasnya tidak efisien, dikarenakan hanya mampu memberikan nilai Contribution Margin (CM) sebesar 49,66\% (indikator kurang dari 60\%), artinya pengelolaan biaya total usaha dagang dalam proses produksinya selama satu bulan termasuk tidak efisien. Dari sisi kelayakan usaha ini sedikit layak dikembangkan di desa Gili Gede Sekotong karena nilai Gross B/C Ratio sedikit diatas 1,0 yaitu sebesar 1,9864. Tetapi menariknya, usaha dagang penggunaan biaya operasionalnya termasuk efisien karena mampu memperoleh nilai Gross Ratio $=47,47 \%$ (indikator lebih dari 20\%), artinya biaya operasional yang dikeluarkan pengusaha sekali proses produksi (satu bulan) lebih $20 \%$ dari nilai produksi yang diperoleh.

1. Nilai dan Jiwa Kewirausahaan Sebelum Pelatihan
Hasil penelitian menunjukkan persentase nilai jiwa wirausaha pengusaha binaan dari penelitian awal sebelum dilakukan pelatihan dan pendampingan didominasi suatu sikap mental/jiwa pengusaha yang sedang dengan skor rata-rata 18,82, lemah 19,00, dan lemah sekali 11,53. Selanjutnya untuk skor kuat dan sangat kuat mencapai skor 1,29 dan 1,12. Melihat hasil rata-rata nilai jiwa wirausaha yang ada pada tabel diatas menggambarkan bahwa dari pengamatan 20 responden wirausaha di Sekotong Tengah menunjukkan bahwa dominasi wirauasaha tersebut berada pada tingkat sedang dengan rata-rata skor 18,82, artinya bahwa mutu dari berbagai aspek kewirausahaan yang dimiliki masih belum kuat dan tidak terjamin kelangsungan hidup (kontinyuitas usahanya).

2. Nilai dan Jiwa Kewirausahaan Setelah Pelatihan

Berdasarkan nilai jiwa wirausaha pengusaha binaan setelah dilakukan pelatihan dan pendampingan, bahwa sikap mental/jiwa pengusaha yang sedang dengan skor rata-rata 19,47, lemah 18,71, dan lemah sekali 10,76. Sedangkan untuk skor kuat dan sangat kuat mencapai skor 1,53 dan 1,24. Nilai rata-rata jiwa wirausaha antara sebelum maupun setelah pelatihan dan 
pendampingan sedikit peningkatan dari kelima kriteria yang dinilai.

Gambaran keadaan diatas merupakan suatu indikasi terjadinya perubahan peningkatan atau pengaruh yang kurang signifikan terhadap pengusaha binaan setelah adanya pelatihan dan pendampingan.

Persoalan/Kendala Dan Pemecacahan Dalam Pengelolaan DWP

Dari hasil FGD, beberapa masalah yang dihadapi dalam pengelolaan Desa Wisata Pantai di kawasan Gili Gede adalah sebagai berikut :

1. Limbah lokal yang dihasilkan dari kegiatan masyarakat yang membuang limbah cair bekas olahan tambang emas rakyat dari daratan diluar kawasan Gili Gede, dan limbah padat khususnya yang terkait dengan konsumsi penduduk didalam kawasan Gili Gede sendiri, tentu ini akan mencemarkan peraiaran perikanan dan laut disekitar kawasan.

2. Penebangan pohon dihutan lahan daratan yang tidak terkendali akan menyebabkan terjadinya dampak turunan seperti erosi yang terpengaruh terhadap kondisi perairan di kawasan desa Gili Gede

3. Terbatasnya air tawar sehingga seringkali masyarakat harus menampung air hujan atau membeli air bersih dari luar kawasan untuk memenuhi kebutuhan rumah tangga sehari-hari.

4. Kondisi terumbu karang di sekitar kawasan Gili Gede sebagian telah mengalami kerusakan yang cukup serius dengan tingkat kerusakan sekitar 40 persen akibat penangkapan ikan dengan menggunakan bom.

Program Pemberdayaan Masyarakat Pesisir Dalam Pengembangan Pariwisata Melalui Pengelolaan Desa Wisata Pantai

1. Pengelolaan SDA :

Melakukan rehabilitasi maupun pelestarian terhadap SDA dan pembuatan awiq-awiq,

2. Pengelolaan Usaha (Kewirausahaan)

Meningkatkan manajemen usaha melalui pelatihan, pembinaan dan pendampingan pada pengusaha

3. Peningkatan SDM :

Memberikan pelatihan ketrampilan dalam pengelolaan SDA dan pelatihan/penyuluhan kesadaran terhadap masyarakat dalam pemanfaatan SDA

Model Pemberdayaan Masyarakat Pesisir Dalam Pengembangan Pariwisata

Besarnya potensi sumberdaya alam (terutama ekosistem laut dan pesisir) dan UKM maupun kesiapan masyarakat dalam 
mengelola komoditi di kawasan pesisir Gili Gede Sekotong merupakan hal yang perlu mendapat perhatian dari berbagai pihak untuk memanfaatkan potensi yang ada melalui upaya pemberdayaan masyarakat dengan menangani potensi lokal tersebut secara baik dan terencana. Melalui pemberdayaan masyarakat dalam pengembangan pariwisata, ekonomi masyarakat diharapkan bisa berkembang/meningkat dan pada akhirnya dapat mensejahterahkan

Pemda (Instnsi Trkit), PT, LSM, Sthokholder

Lembaga

Perbankan

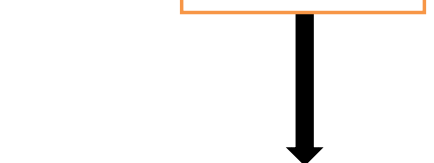

Permodalan masyarakat yang ada di kawasan pesisir Gili Gede Sekotong.

Berdasarkan hasil diskusi terbatas melalui Fokus Group Discussion (FGD) yang dilaksanakan Tim Peneliti dengan dihadiri peserta dari pelaku usaha (UKM), tokoh masyarakat dan pemuda terdapat beberapa tanggapan dan masukan yang dapat dirumuskan sebagai program/model pemberdayaan masyarakat dalam pengembangan pariwisata yang dibuatkan bagan seperti berikut ini:

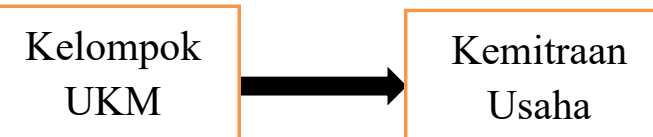

Psr:lokal,

Nasional

Usaha

Ketrp.SDM +

Pngloln.SDA

Dari

bagan

program/model

pemberdayaan masyarakat tersebut, dapat dijelaskan sebagai berikut :

1. Peran serata dari berbagai pihak seperti Pemerintah Daerah (instansi terkait), Lembaga Perbankan, Perguruan Tinggi, LSM dan stakeholder sangat diperlukan dalam hal bantuan modal usaha,

pembinaan/pengembangan SDM (ketrampilan) dan pelatihan/penyuluhan, tanpa ada komitmen ini upaya yang akan dilaksanakan pasti akan gagal.

2. UKM penting diperlukan sebagai peran dalam menggerakan ekonomi masyarakat dalam pengembangan pariwisata di kawasan pesisir Gili Gede 
Sekotong, oleh karena itu perlu membentuk Kelompok UKM.

3. Perlu adanya jaringan/kemitraan usaha yang dapat memperlancar kegiatan/operasional usaha dalam rangka pemberdayaan masyarakat pesisir.

\section{KESIMPULAN DAN SARAN}

\section{Kesimpulan}

Dari hasil penelitian yang diuraikan diatas dapat disimpulkan sebagai berikut :

1. Kawasan Gili Gede berpotensial bagi pengembangan pariwisata melalui Wisata Desa Pantai, karena memiliki ekosistem pesisir dan laut yang menarik dan indah serta dapat diracik sebagai atraksi wisata seperti berperahu, snorkling dan diving.

2. Dalam pengembangan Desa Wisata Pantai dikelola secara marketable (berkelanjutan) dengan dukungan pihak Pemerintah Daerah, Stokcholder, LSM dan Perguruan Tinggi. Pengembangan tersebut harus melibatkan/partisipasi dari masyarakat agar memenuhi kebutuhan wisatawan/pengunjung , sehingga akan dapat meningkatkan kesejahteraan masyarakat

Permasalahan yang terjadi di kawasan Gili Gede, berdasarkan FGD adalah
Sumberdaya manusia yang masih rendah, sehingga tingkat pengetahuan dan ketrampilan kurang, Pengrusakan terhadap ekosistem peisisir dan laut ,Penebangan hutan oleh masyarakat setempat, Modal usaha kurang, sehingga usaha yang dilakukan tidak bisa berkembang

Dari tiga usaha yang dianalisis secara ekonomi memang menguntungkan, dan juga yang paling layak/unggul dikembangkan untuk sementara di Desa Gili Gede yaitu usaha abon ikan tongkol dan beternak kambing, sedangkan usaha dagang sedikit layak

Nilai jiwa kewirausahaan dari sebelum dengan setelah pelatihan, pembinaan dan pendampingan terdapat perubahan prosentase kenaikan yang relatif kecil antara 0,12 persen, 0,24 persen, 0,65 persen, 0,29 persen dan 0,39 persen terhadap lima kategori kuat sekali, kuat, sedang, lemah dan lemah sekali.

Tersusunnya

Model/Program

Pemberdayaan Masyarakat Pesisir Dalam Rangka Pengembangan Pariwisata Melalui Pengelolaan Desa Wisata Pantai Gili Gede. Saran

Solusi memecahkan permasalahan di kawasan Gili Gede dilakukan dengan program pelatihan, pembinaan dan pendampingan agar dapat meningkatkan 
ketrampilan, pengetahuan dan kesadaran masyarakat dengan melibatkan Pemda, Stockholder, Perguruan Tinggi dan LSM Hendaknya kegiatan pembinaan dan pendampingan dilakukan secara teratur, tertib dan disiplin serta kontinyuitas.
Membentuk Jaringan usaha bermitra derngan pihak lain yang berkompoten seperti Pengusaha/stockholder, Lembaga Perbankan

\section{DAFTAR PUSTAKA}

Ananimous, 1981, Tourism Development Plan for Nusa Tenggara, Indonesia, World Tourism Organization, UNDP and WTO, Madrid

Anonim, 2000, Work Shop Singapura Airlines, Desa Wisata, Singapura

Anonim, 2006, Pengabdian Kepada Masyarakat di Gili Gede Sekotong Kab.Lombok Barat, Konsursium Mitra Bahari (KMB) NTB

Anonim, 1997, Arah Kebijakan Pengelolaan Pesisir dan Pantai Propinsi NTB, Mataram

Anonim, 2016, Profil Desa Gili Gede, Sekotong

Achmad E, dkk, 2003, Pengelolaan dan Perencanaan Terpadu Sumberdaya Pesisir Kecamatan Sekotong Lombok Barat, NTB. Small-Scale Natural Resurces Management Schemes MCRMP

Achmad E, dkk, 2009, Model Pemberdayaan Masyarakat Pesisir Melalui Pengelolaan DWP Berwawasan Kerakyatan dan Lingkungan Di Kawasan Gili Gede Lombok Barat

Achmad E, dkk, 2011, Pengentasan Kemiskinan Melalui Pembinaan Sikap Mental Wirausaha Pada Masyarakat Pesisir Desa Kebun Talu Labuhan Tereng Kecamatan Lembar Lombok Barat Alma, 2000, Kewirausahaan Panduan Perkuliahan, Penerbit Alfabeta, Bandung Jufri A, dkk, 2015, Pembinaan Wirausaha UKM Dalam Rangka Penguatan Ekonomi Masyarakat Di Kawasan Pesisir Desa Sekotong Tengah Kabupaten Lombok Barat Kay R, 1999, Coastal Management and Planning, E \& FN SPON, New York Nikujuluw, V, 2011, Penyusunan Rencana Pengelolaan Kawasan Pesisir dan Laut * 2005, Promoting Small and Medium Enterprises With a Clustering Approach : A. Policy Experince From Indonesian, Journal Of Small Business Management, Vol. 43, No.2 Syah K, 2003, Paradigma Baru Parawisata Bahari, Sinar Harapan 3 Juli 2003, Jakarta World Bank, 2001, World Develompment Report 2000/2001, Attacking Poverty 
I52 Masrun,Aאhmad Jupri, M.Firmansyah/Pemberdayaan Masyarakat Pesisir...

Yao, Guevera Assamoi, 2007, Fiscal Decentralization and Poverty Reduction Outcomes,

Theory

and

Evidence,

George

State

University. 